Volume 6, Issue 1 (2017) 33-48 | Published online 18 October 2017

The publication of the JEOD is supported by the Autonomous Province of Trento, Italy

\section{AUTHOR}

GIOVANNI TENEGGI

Confcooperative Reggio Emilia (Italy)

teneggi.g@conf.cooperative.it

\section{FLAVIANO ZANDONAI}

Euricse and Iris Network (Italy)

flaviano.zandonai@euricse.eu

\title{
The Community Enterprises of the Appennino Tosco-Emiliano UNESCO Biosphere Reserve, Italy: Biodiversity Guardians and Sustainable Development Innovators
}

\section{ABSTRACT}

The UNESCO recently designated the Appennino Tosco-Emiliano as a biosphere reserve (BR) in 2015. On the reserve territory, it is possible to rediscover the constitutive elements of this environmental, socioeconomic and historical-cultural space. In particular, the existence of different stratifications of social entrepreneurship represents a valuable element that the biosphere is expected to enhance and spread to other territories. In addition to consolidated social economy experiences, some organisational innovations, such as community enterprises, are in fact developing. Originating from processes of social resilience, these enterprises contribute to redefining the supply of collective interest services, by basing themselves on the regeneration of economies and place-based resources and by challenging the territorial governance models in terms of greater inclusivity.

\section{KEY-WORDS}

BIOSPHERE RESERVE; COMMUNITY ENTERPRISE; SOCIAL RESILIENCE; LOCAL DEVELOPMENT

JEL Classification: Q01; L31; L38 | DOI: http://dx.doi.org/10.5947/jeod.2017.003 


\section{Introduction}

The biodiversity of the Appennino Tosco-Emiliano does not only concern the presence of environmental resources that are protected by a national park founded in 2011 and span a mountain area of more than 22,000 hectares in the northwest part of Italy. The same feature can also refer to a series of communitarian organisations that have developed over time in the same territory, thus contributing to creating a sustainable relationship between people and nature. The UNESCO's placement of this biosphere reserve (BR) under the Man and the Biosphere (MAB) Programme therefore seems the natural outcome of the process that concerns not only the story of this land but also its current reality and probably its future. In this sense, the biosphere, besides representing the realisation of a completed process, is also the base on which to reconstruct a socio-environmental ecosystem that will establish a new equilibrium among its parts in order to face new challenges, even with regard to the recent past. Briefly, these challenges concern the human presence in a territory (especially in the central area of the BR) that knew not so much an excess of pressure but a process of progressive abandonment.

Given this research topic, in Section 1 of this paper, we attempt to reconstruct the recent evolution of the Appennino Tosco-Emiliano biosphere, in terms of the identification of its needs and resources to regenerate, by particularly drawing from the contents of the BR application dossier submitted to the UNESCO. In Section 2, through the research data, we analyse the different experiences of the community enterprises characterising this territory in a recurrent and significant way, and we try to establish continuity and discontinuity links between different phenomenologies. In Section 3, we identify the learning elements stemming from more recent and innovative experiences of communitarian entrepreneurship in the BR area. These elements are useful in revising policy-making processes and the supporting processes of these enterprises, in a way that enhances their development and diffusion in both similar socio-environmental areas and new contexts.

\section{The environment of the biosphere as historical-cultural matrix and socioeconomic infrastructure}

The UNESCO designated the Appennino Tosco-Emiliano as a biosphere reserve only in 2015, but the process took a relatively short period from the submission of the application in September 2014. Despite its recent designation as a reserve, it contains many constitutive elements of the biosphere model, which probably contributed to accelerating the process of being awarded the status by international competent authorities.

Analysing the application dossier (Parco Nazionale Appennino Tosco-Emiliano, 2014) makes it possible to identify at least three macro-elements that directly recall the archetype of the socioenvironmental infrastructure represented by the MAB Programme. 
First, the Appennino Tosco-Emiliano biosphere may be represented as a historical-cultural matrix deeply embedded in the environment and landscape, in a relationship of mutual influence and co-evolution (Dasgupta, 2004). The presence of particular animal and vegetal species in the territory is linked not only to strictly climatic and geographical variables but also to the fact that historically, this area of the Appennino represented a human settlement space and an important junction between different regions. As recalled in the biosphere vision document (UNESCO, 2015), it is a ridge that represents a real border, not only from a climatic perspective, but also at historical and cultural levels, between Continental and Mediterranean Europe. This deep and differently stratified matrix goes back from prehistory to the present time.

Second, on this important constitutive element we can situate the activity programme outlined in the application dossier, which had to be drafted on the basis of the MAB Programme guidelines, that is, the preservation of environmental resources to foster biodiversity, socioeconomic development targeting sociocultural sustainability, and training focused on research activity and capacity building for local communities that in several respects are present in the territorial area recognised as a biosphere (Parco Nazionale Appennino Tosco-Emiliano, 2014). The Appennino Tosco-Emiliano proposition concretely combines these three elements into one action programme aimed at strengthening the complementarity between economic development and environmental protection, thus enhancing the human capital in terms of resilience. Similar to comparable areas at the national level, over the last decades, the biosphere territory has been subjected to transformation processes that require reformulating the fundamentals of social, economic and environmental development (Lo Bianco, 2016), as follows:

- At the social level, we notice a long-term depopulation trend in mountain areas and some migratory phenomena of younger groups of the population to urban areas surrounding the BR (represented by cities such as Milan, Genova and Bologna) and to larger towns in the area, thus fostering their urban development and the acquisition of infrastructures and services.

- The economy has progressively polarised in some territorial areas and in market segments where it is easier to develop economies of scale by exploiting technologies and logistic resources, especially localised assets in agricultural and artisanal production. The service economy remains secondary and suffers from both the progressive shortage of public supply and the scarcity of dedicated infrastructures (e.g., the broadband internet connection).

- As far as the environment is concerned, the abovementioned social and economic processes have broken the ancestral symbiosis between people and nature, leading to negative externalities, not because of an excessive human presence, but following a progressive and usually quick deanthropisation of the territory (e.g., in terms of hydrogeological instability due to the reduction or the absence of forest and river maintenance).

On this cognitive basis, the Appennino Tosco-Emiliano BR chose to focus on strictly intertwined domains, such as sustainable agriculture and social tourism, involving in particular young people who. In this historical phase, young people are an ever-scarcer resource in the 
BR due to the evident depopulation trends, thus causing imbalances from a social perspective (increase of the seniority index) and deficits in terms of social mobility, availability of specialised competencies and inclination toward innovation and entrepreneurship. In fact, it is necessary to relaunch a new development cycle in an area that is still rich in environmental and cultural assets, which built up important economies that, starting from the local dimension, had a broad impact on the agri-food supply chain.

Third, the application dossier shows the involvement efforts of different institutional actors present in the territory, not only because of the needs linked to the zoning of the place into core, buffer and transition areas (UNESCO, 2015), but also to define a system of governance of the BR that is consistent with a plurality of actors and their administrative, functional and policymaking competencies. In fact, the BR territory shows a remarkable institutional biodiversity, encompassing a national park, two regions, four districts, 32 municipalities and other public and public-private techno-structures that have been formed to plan and manage economic resources, in most cases coming from the European Union and linked to development policies on a local scale. From this perspective, qualifying as MAB BR embodies both an opportunity and a risk. On one hand, the designation may represent another improvement of the territorial governance that is fed by new institutional dialogue models prompted by the participation in a development programme that is incorporated in a single infrastructure of environmental, landscape, economic and social assets. All these resources (as mentioned) are constitutive features of this territory. In this sense, the recently constituted BR may be configured as a structure that is able to intermediate among different policy devices that currently appear fragmented in terms of attribution and responsibility, particularly regarding the strategies for economic development, social cohesion and protection, and promotion of environmental and cultural heritage. On the other hand, there is also the risk that the BR will be considered another coordination level that weighs down the institutional dialogue and does not manage to engage other social and economic actors according to a model of multi-stakeholder policy, as required by the MAB Programme guidelines (UNESCO, 2015).

To achieve this aim and complete the analysis of the institutional framework, it can be useful focusing on the role played by the social and cooperative enterprises in the territory of the Appennino Tosco-Emiliano and more generally, in the broader context of the so-called Italian internal areas that are visually represented in Figure 1. These territories are the objects of a national development strategy and are defined according to modalities that have several aspects in common with the MAB Programme. In fact, the inner areas are "far from the centers where essential services (education, health and mobility) can be found, rich in important environmental and cultural resources and extremely diversified following secular anthropization processes" (Barca, Casavola and Lucatelli 2014: 7). 
Figure 1. Urban network and rural and peripheral areas in Italy

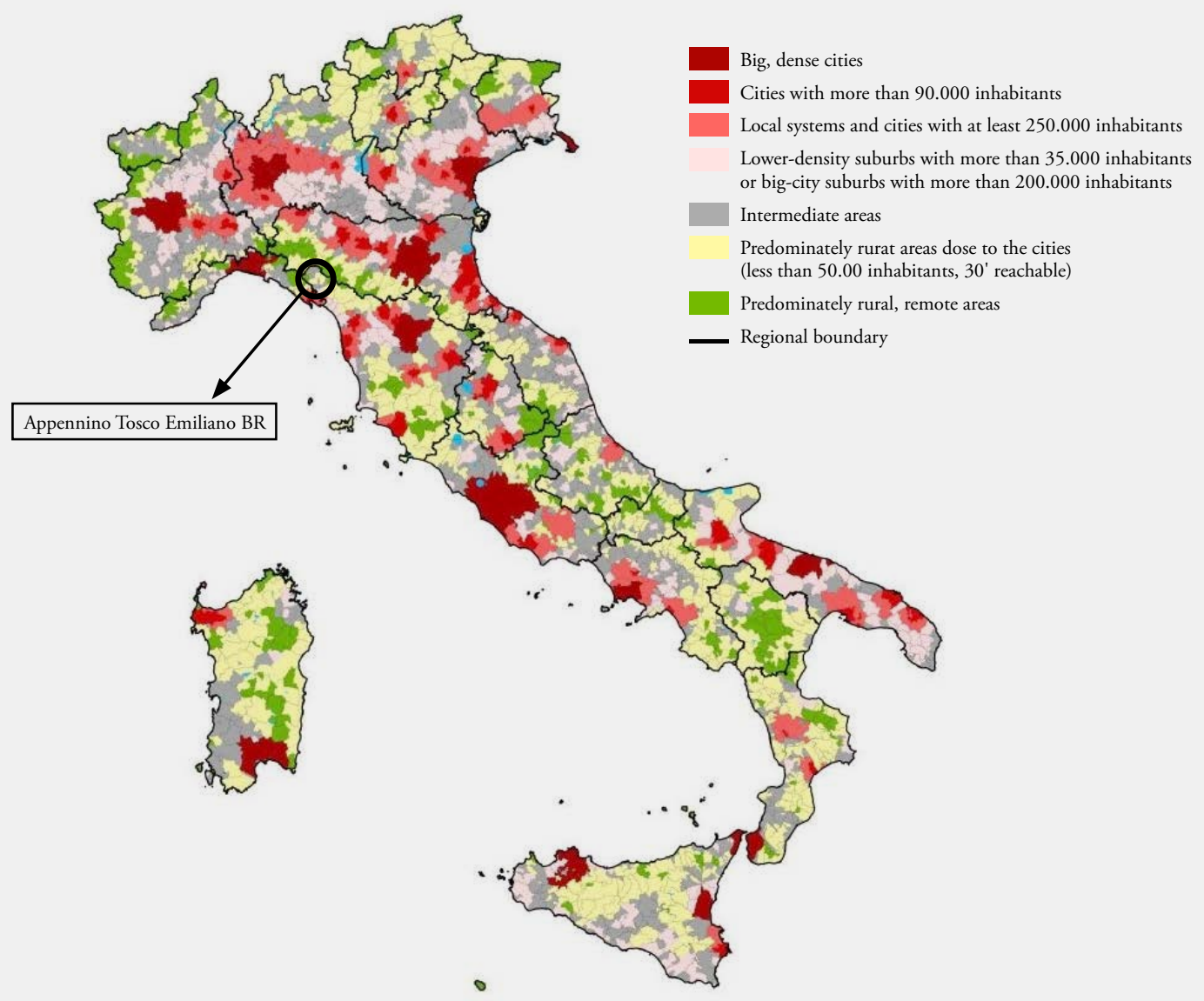

Source: Ministry of Economic Development-Invitalia 2016

The presence and the characteristics of different forms and models of social entrepreneurship (European Commission, 2016) thus represent important feedback, not only because the MAB application dossier required information on the modalities and the features of local communities' engagement. Another reason is that the Appennino Tosco-Emiliano and many other parts of the national territory that are similar in geographic and socioeconomic structures are characterised by the stratification of social organisations engaged in the management and the regeneration of local resources to satisfy the needs of the local residents.

It is possible to synthetically identify at least three different evolutionary levels of private social and economic organisations operating in the management of territorial assets by adopting models of inclusive governance (Sacchetti and Campbell, 2017).

The first level consists of systems regulating the use of environmental resources according to collective 
property models. It deals with forms of governance of goods recognised as having a common interest and stemming from the emerging process of institution building on a communitarian basis that were particularly common from the Middle Ages up to the modern era, especially in rural communities in the alpine and apennine areas (Casari, 2007). These management models of common pool resources are still present in some areas, even in the Appennino Tosco-Emiliano. In some cases, they are gaining popularity again, especially regarding the re-use of abandoned or underused infrastructures and resources (e.g., uncultivated lands) to launch new activities, usually taken up by people (e.g., the young generation) who feel excluded or discriminated against in the ordinary labour market (Sacconi and Ottone, 2015).

The second level is represented by the progressive development (especially in the period between the modern and the contemporary eras) of cooperative enterprises. Such advancement has allowed the creation and the management of production chains, particularly in the agricultural and food sectors, by associating local producers (often family businesses), that manage to protect the distinctive quality of the production and connect it to the environmental and (in a broader sense) cultural characteristics of a well-defined territory (Borzaga and Tortia 2017). Particularly, the area of the Appennino Tosco-Emiliano BR is characterised (as often mentioned in its application dossier) by a wide variety of agro-food productions that are managed through enterprise networks organised in agricultural cooperatives, balancing the value deeply rooted in the territory (scaling deep) with the development of extra-local market economies (scaling out) (Riddell and More, 2015). In some cases, the goods represent the excellence of Italian agro-food production (e.g., parmigiano reggiano cheese). In other cases, they are products whose origins are linked to the rediscovery of localised productions intertwined with the advocacy process and new production and consumption models (local food, fair trade) and recognising the value of bottom-up initiatives that are usually launched in marginal areas according to modalities typical of the social economy paradigm (Utting, 2015).

The third level concerns the more recent origin (i.e., in the beginning of the 21 st century) of community enterprises, unifying the valorisation of local economies and the co-production of collective-interest goods and services (Mori, 2017). Community enterprises, usually organised as cooperatives, are an extremely fluid and dynamic phenomenon that stems from collective resilience processes following environmental and socioeconomic shocks. This phenomenon recently became the object of attention, both at a normative level in a local context and through the actions promoted by the Ministry of Economic Development for support and replicability purposes. The Appennino Tosco-Emiliano BR (as detailed in the following section) is one of the main epicentres of this phenomenon because some pioneer community enterprises operate there. Moreover, this territory has hosted for a five years a school of community cooperatives that summons social entrepreneurs, policy makers and other practitioners at the national level (Farina et al., 2017).

Despite both consolidated and dynamic organisational forms aimed at the management of production and the governance of collective goods by repositioning them at a communitarian level, the BR application dossier and more generally, national intervention programmes (such as the strategy for internal areas) do not explicitly refer to the contributions of these different realities of 
social entrepreneurship. The scarce acknowledgement of policy design-also reflected in terms of involvement and support-thus outlines an action field for implementing policies that promote community enterprises and societal infrastructures for a territorial governance that should become even more inclusive and turn into organisational innovations (i.e., new schemes of production of goods and services for sustainable sociocultural and environmental development). Investigating their constitutive characteristics and development processes therefore represents an interesting element in two ways. First, it allows for a more precise definition of the organisational design of collective social and entrepreneurial initiatives that (especially in territories characterised by distributed and polycentric resources) are less and less framed according to the typical schemes of state institutions, the market and the social economy itself, particularly in terms of ownership and governance (Sacchetti and Campbell 2017). Second, the connection with and the multi-local replicability of good practices through platform devices, such as OASIIS ${ }^{1}$ (ASC, 2013), may trigger a development process, aimed not only at balancing local rooting and global diffusion, but also at fostering systemic changes (scaling wide) (Riddell and Moore, 2015). Such changes intend to revise the rules of the game that concretely correspond to the innovation of processes and policy devices (e.g., those of the MAB Programme) in the territorial area, where environmental resources are in close contact with the dynamics of economic and social development.

\section{Re-emergence processes of community enterprises: discontinuity elements for a new life cycle}

Over the last decade, in the Appennino Tosco-Emiliano, particularly near the core BR area, two new cooperatives have emerged: Briganti del Cerreto located in Cerreto Alpi, and Valle dei Cavalieri, in Succiso Nuovo. These enterprises have contributed to redefining the supply of local public utilities by investing on a wide variety of goods and services-from welfare to proximity trade and from logistics to environmental protection — and by restoring local activities and traditions that managed to intercept external economies, especially through touristic and cultural opportunities.

These community enterprises are the object of a narration that has inspired other initiatives, particularly in similar areas, and most recently even in different contexts, such as those of suburban areas (Mori, 2017). According to the most recent survey (Borzaga and Zandonai, 2015), Italy has at least 100 enterprises that are explicitly formed as community cooperatives. However, according to operating officers (e.g., representatives of cooperative federations, local foundations and public entities who support the development of these entities), the number of community enterprises should be even higher, considering the existence of other non-profit institutions (particularly associations) and informal groups linked to environmental advocacy initiatives, the protection of common goods, cultural protection, safeguarding of agricultural and craftwork production, and so on.

Opening Access to Sustainable Independent Income Streams. See: www.oasiis-br.org 
Therefore, examining the pioneer experiences occurring in the Appennino Tosco-Emiliano BR makes it possible to understand the peculiarities of a phenomenon that has developed by both expanding and diversifying. For this reason, it is particularly useful to focus on emergence processes and constitutive characteristics, thus emphasising continuity and discontinuity in relation to similar experiences (e.g., of cooperatives, social enterprises, other non-profit institutions) that contribute to the institutional biodiversity of this territory.

The generative processes of new communitarian enterprises and more generally, of the origin and consolidation of new cooperative economies, represent a knowledge process that can be situated between the abstractness of normative structures and the relativism of the narration. These processes, whose evolution is not always linear, are linked to social innovations that stem from a slackening of the strict subdivision among institutional spheres (state, market and civil society) and among the roles of the subjects involved in the supply of goods and services (producers/consumers) (Daskalaki, Hjorth and Mair, 2015). In the following points we try to summarize the main processes.

The first generative factor concerns the enhancement of environmental and historical-cultural resources, usually undervalued or not recognised as such. The economies generated by these material and immaterial assets have value in themselves (i.e., they are inspired by environmental and social sustainability paradigms). Moreover, they possess an instrumental value because they produce and redistribute resources in favour of other social initiatives, which cannot guarantee their economic sustainability, for different reasons (Colucci and Cottino, 2015).

A second factor involves the promotion of partnerships among different actors-especially along the public-private continuum - who act not only in the policy-planning domain but also on the reciprocal co-responsibility in terms of resource attraction and co-management of initiatives. From this perspective, community enterprises can be entirely placed in the context of multi-polar administration in contrast to bipolar models, where public administration addresses external actors exclusively as suppliers of goods and services. In most cases, this process is not linear and is usually characterised by conflicts between these emerging organisations and public institutions. However, the outcome tends to define a new way to recompose the public-private partnership by considering the common dimension of available goods and services (Foster and Iaione, 2016).

The third and last generative factor concerns the mentioned diffusion of production models where beneficiaries play an active role in the phase of planning and managing activities (Pestoff, 2012). These forms of presuming represent important challenges concerning the acknowledgement and the regulation of action modalities where the traditionally separated roles of producer and consumer are strictly connected.

Instead, by considering their constitutive characteristics, we can identify some common criteria to recognise communitarian enterprises, in particular according to a cooperative model (Euricse, 2016).

They produce goods or services in a stable and continuous way, drawing from processes of regenerating physical or immaterial goods of common property. These common goods serve as infrastructures, enabling further economic or social activities that can be carried out even outside the organisational contexts of the community enterprises. These organisations operate as multi- 
functional community hubs that can be adapted according to different ways of production and management, besides being business models that are inspired not so much by economies of scale but by economies of scope (Battistoni and Zandonai, 2017).

These organisations are owned and managed, completely or primarily by people on the basis of inclusive and democratic principles. For community enterprises in a cooperative form, the value driver is represented not so much by the internal mutuality among associates with similar interests and needs but by the principle of concern for the community (MacPherson, 2013). Therefore, each one is an open and development-oriented organisation by guaranteeing all community members non-discriminatory access to goods and services.

They are deeply rooted in a community because their ultimate objective is the improvement of the quality of life of a local community, intended not only as the totality of the residents in a certain territory but also as a group of people who share values, cultures, interests, resources and projects in various ways, even if they do not live in the same physical space. The latter aspect is particularly important for organisations operating in micro-contexts where available resources (environmental, social and economic) are not sufficient to guarantee minimal living standards. Moreover, this would mean not enhancing external resources that could be used to increase their social and economic impacts. For example, we can consider the stakeholder group represented by immigrants, who may represent for many community enterprises an important resource for the sustainability of their social business and enrich the governance with needs and aspirations of a different nature, that can be situated in a local dimension as a context of shared and common meanings (Sacchetti, Christoforou and Mosca, 2018).

A community enterprise therefore represents an organisational innovation that captures the discontinuity of the current historical phase and realises itself on various fronts (from economic crises to environmental catastrophes) and with more intensity, by generating answers in terms of changes that are increasingly analysed by emphasising resilience. This concept is characterised by the plurality of its meanings and a broad scope of applications-from materials engineering to human psychology and organisational and management systems. In its social decline, resilience refers to the quest for a new equilibrium among socioeconomic functions, social relations and environmental changes following widespread and progressive shocks. In this sense, the crisis of socioeconomic and environmental systems manifests itself through a significant alteration of traditional balances on which the endurance of communities and ecosystems was based. The effects of this modification are visible through apparently diversified manifestations, including social marginality of wide and varied social groups, soil consumption, worsened environmental conditions, among others. In reality, these phenomena can be closely related by amplifying the risk dimension and thus prompting the identification of new forms of collective action for communities wishing to react in order to stop this negative spiral.

From this perspective, rather than a solution, social resilience is more of a working methodology aimed at dealing with changes in a proactive way, not merely adapting to them. In its more extreme realisation, within a very short time (e.g., in the case of an environmental catastrophe), 
the scale of problems drastically overwhelms available resources, thus interrupting (or hindering) the routine that until then ruled the systems of social relation. Following the shock, physical and social environment becomes a fertile ground for the emergence of new action modalities and novel organisational forms, on the condition that it manages to support natural reactivation processes that can realise themselves even in an embryonic or precarious form (Lanzara, 1993).

These features are the basis for the development of a learning model of the resilience practices, based on two fundamental aspects that were also emphasised by communitarian entrepreneurship experiences that (starting from the Appennino Tosco-Emiliano BR) are now widespread at the national level. First, this ongoing process is developing, both in an incremental sense (from the idea to the project) and as a bottom-up experience (from micro to macro). Second, this kind of learning is always relative and strategic by taking into account the starting conditions (available resources and context data) and the type of challenge to face, as well as focusing on the characteristics of the problem and the opportunities that can be derived by facing it. The most relevant aspect of resilience processes entails recognising and then following those "creative acts of project design" that contribute to reinventing the environment by operating on the spaces left free from the already compromised status quo (Colucci and Cottino, 2015: 39). The often ephemeral character of these initiatives is the outcome of small group intuition and requires the simultaneous activation of a connective communitarian network that the members will help strengthen by adapting it to new conditions. The contamination of resilience initiatives particularly occurs due to the identification of relatively defined problems around which various actors unite, by setting up transversal links that go beyond traditional cultural and ideological matrixes, territorial belonging, sharing of juridical forms, and so on (Sacchetti, Christoforou and Mosca, 2018). This pragmatic approach in the form of a community project is based on well-defined and measurable drivers, such as the reuse of abandoned properties, which reactivate the network of relations according to new modalities (Cottino and Zandonai, 2012). Therefore, the processual dimension of resilience clearly emerges. Indeed, the central aspect involves the transition from the intuitions of active minorities that recognise some value-added elements in discontinuity, to real enterprises serving to benefit the community by valorising the resources of the community itself.

\section{What can be learned from processes of social resilience and regeneration?}

It might be hypothesised that people in some mountain villages no longer distinguish between public and private properties. The reason is that the local community gains the maximum value from public places by assigning them social and economic functions. At the same time, they perceive private shops and businesses as public properties because these establishments play a crucial part in everybody's lives (Farina et al. 2017). Situations such as this might be deemed cutting-edge workshops of economics and finance. Matters are different in the large universities and the centres of innovation and technology transfer. Despite all the mathematical models and theories, these 
institutions have not yet proven capable of developing this new socioeconomic formula that no longer distinguishes between public and private properties and between social and commercial realms. These institutions establish the same genetic code for both social matters (rekindling the economic role of satisfying citizens' needs) and the economic sphere (restoring the social role that advanced democratic constitutions and people profess to perform) (Domanski and Kaletka, 2017).

While these domains have evolved as separate, distinct entities throughout the 20th century until the present day, the extraordinary, innovative phenomena under study can be observed in their natural habitat in the villages and the valleys of the Appennino Tosco-Emiliano as a UNESCO BR. In the many villages that are the mainstays of the area, such as Succiso, Cerreto, Corniglio, Sologno and Apella, the communities have proven enterprising and cooperative due to their need for resistance and then for development. It is a matter of pursuit of happiness. They have taken different approaches and told different stories, but they have all defied the laws and the powers of the market and the institutions. In some cases, the inhabitants have formed cooperatives that have revitalised public places by making productive businesses out of them and have helped private businesses on the verge of closing to continue as commons (such as the Valle dei Cavalieri in Succiso). In some cases, the residents have promoted short supply chains and networks of local companies that offer distinctive products and appeal (such as Montagna Verde and the Lunigiana area in Apella). In other cases, they have created small social market economy districts involving business and non-profit players (such as in Cerreto with ties among the local sports association (CSI), the Giovanni Lindo Ferretti Foundation, the Briganti del Cerreto cooperative of young workers, the local parish and an array of businesses). In several cases, they have started with cultural initiatives to re-forge ties and activate dormant resources and assets that were previously neglected due to a feeling of resignation but revived by a new enterprising spirit and a fresh sense of opportunity (such as in Corniglio with the cooperative Cento Laghi). In the natural habitats formed by people and communities in areas that are deemed distant and vulnerable, we can observe phenomena that the economic literature and social research were neither watchful enough to notice nor bold enough to think about.

The Appennino Tosco-Emiliano BR is home to no fewer than 64 Protected Designation of Origin (PDO) and Protected Geographical Indication (PGI) products, but its most important output is trust, which is produced and distributed daily by the experiences described above. The community enterprises are factories of social cohesion that keep up the quality of life in the territory. Trust is the most important product in these settings, and the enterprising communities are the producers (Lo Bianco, 2016). What are the conditions and the factors behind the development of trust?

A basic condition is that people, social groups and companies are needed. They do not necessarily have to be already present and available (in many cases, setting in place the initial conditions is a long and delicate process), but their initial presence and development are important. As well as local inhabitants, the need may be met by people returning to the area or even by those from outside the community. The crucial factor in ensuring that all presence of this kind is productive for both the community and the economy lies in a vocation and a public pact to make the territory a home. Rather than simply residing in the area, people who make it their home establish relationships with 
the place and with their fellow inhabitants, publicly demonstrating their need and desire to do so. The same applies to businesses and companies that do not simply settle in the territory but permeate it and its community, making them part of their production or supply chains. The home-making pact thus generates a pledge for a profound relationship that-even before mutual support and activities - establishes joint destinies. It resembles the situation in rural and mountain communities in previous centuries; people and their families were bound together in their similar activities, not for profit but for survival and a shared destiny.

Home-making and relationship pacts produce and support pacts about places and the physical identity that is built on the public sites that embody a village and its associated quality of life. It is no coincidence that many of the processes behind the development of enterprising communities spring from the fear of losing a common ground for interacting and socialising, such as a café/bar, a theatre or a square (Colucci and Cottino, 2015). After a dramatic earthquake and landslide, the closure of the bar in Succiso actually led to the decisive concerns about the demise of the community and gave the people the strength to react. Similarly, for many years, the bar of the community centre in Cerreto was the focal point of its resistance and lay the foundations for other initiatives, including on the economic front. As well as a place for drinking and telling stories, it is also home to a shop and a surgical clinic.

Enterprising communities with permeating companies or cooperatives of inhabitants salvage forgotten physical spaces and turn them into sites for living, interacting or working once again. Following trust, home making and relationships, production sites are the assets responsible for the protection and the competitiveness of the Appennino Tosco-Emiliano BR, which is guiding similar interior areas of Italy along the same path as part of a national strategy dedicated to them. Working alongside the Italian Ministry of Economic Development, the regions of Emilia-Romagna and Tuscany have selected the BR as a model and a site for further experimentation. In the next future, strategic agendas will be established for the associated investments, focusing on health, transport and school services, as well as economic development (Ministry of Economic Development-Invitalia, 2016).

As mentioned, salvaged sites can be assets for the development of the territories in question. The process of reaching maturity and investing will only be realised in enterprising communities if the foundations described above have been laid. In turn, this very process is indispensable if the communities intend to follow the subsequent steps and be developed into economic districts. Numerous examples are offered by both the cases themselves and the administration methods behind them. In all cases, an investment by a socioeconomic player (a community cooperative or a local company) embodies and highlights not only a cultural identity in urgent need of outlining but also a distinctive economy to be created profitably. Whether it involves an area of a village, a mill, an old room in a town hall, a forest or a square, there are always unprecedented relationships between public and private entities. A public body (the national park administration or the municipality) authorises the work and the enhancement process, asking for the standing of the community and the public property to be improved over the long term. A private company provides technical 
support, assumes the business risk and makes the initial microfinance resources available. An enterprising community can provide the project with the informal inputs in terms of its identity, promotion, work, relationships and maximised value that are crucial for its success (Euricse, 2016). After all, the site will chiefly belong to the inhabitants, as it is returned to them. Obviously, over the long term, the reward for everyone-on top of employment and the recovery of the resources used in a satisfactory financial balance-lies in history and life. It is a real pivot for economic development and innovative thinking in these locations. Speculation is not-and cannot bemerely of a financial nature. Production factors cannot be optimised in accordance with the market standards because such an approach would be untenable.

Investments in credible projects in the territories in question are made by individuals who are searching for an identity from the past and a life for themselves and their children in the future.

As part of the general comparison and exchange of good practices among UNESCO BRs, one last step can be highlighted in the socioeconomic configuration of the Appennino Tosco-Emiliano BR. It concerns the institutional functions and vocation of the enterprising communities with their community businesses. The cohesive and governing functions of their actions are natural and contribute to the institutional roles expected by political institutions. In this respect, the presence of a strong political framework and culture that foster territorial protection and participation is another key aspect in the initiation of the processes in question. Our area is no exception to this rule. Examining our procedures reveals that the less state, more society concept does not reflect reality in our case. Throughout the territory, in both the past and the present periods, we have observed that the presence of institutions and formal democracy has facilitated the development of social initiatives and capabilities (Mori, 2017). Thanks to this positive cooperation, significant portions of the territory find that the responsibilities of the communities and their companies offer representation that is indispensable for the effectiveness of the appointed public institutions, with which they converse, collaborate and negotiate (Barca, Casavola and Lucatelli, 2014).

The new horizons opened up by the UNESCO MAB recognition are in contrast to the gravest perils for community ventures such as this, involving self-referential outlooks and splintered accounts of the (albeit positive) developments in the territory. The danger is that there will be many similar but slightly different stories that can only be told on a case-by-case basis. A BR that manages to unify all the narratives in a vast but uniform single territory will make it possible to follow a common path. The entire area will have the ability to become an economic and social district that can count on greater ecosystemic relations and a single social and economic supply chain (Rizzi and Teneggi, 2013).

The World Network of Biosphere Reserves (WNBR) and the distinguishing OASIIS network offer the ideal reason for embarking right now on this process of unifying horizons and destinies. The need and the allure are clearly reinforced by the OASIIS network worldwide. Significant appeal and attraction are generated, especially with regard to young people who offer an essential incentive to build for the future. 


\section{Conclusion}

In its recent history and for the future, the Appennino Tosco-Emiliano BR presents itself as a space that expands three important environmental features on the socioeconomic front.

The first one concerns biodiversity in a broad sense, referring to the presence of public and private entities (profit oriented or not), both institutionalised and informal types that are based in the territory and operate in various ways on the main development axes — supporting local economies, contributing to social cohesion and actively protecting environmental resources (Dasgupta, 2004). Therefore, we are not dealing with specialised actors in a sectorial or functional way but with mission-driven actors, that is, with the capacity to recombine all these different elements according to their objectives and the vision characterising them.

The second feature corresponds to the ecosystemic nature of BR, referring in this case to a broader capacity to attract and unify resources of different origins with the aim to foster a development model to which different actors contribute (European Commission, 2016). In this sense, the BR represents not only the stronghold of a local context but also an infrastructure contributing to the government and the management of socioeconomic fluxes on a global scale, by intercepting new production and consumption models that are no longer exclusive (e.g., at a touristic, agricultural, cultural level). This situation requires that the elements of safeguarding environmental axes and local products be transformed into production factors within the supply chain of a shared value among different stakeholders.

The third feature that broadly characterises the Appennino Tosco-Emiliano is derived from biology and consists of the adoption of cooperation, not exclusively as a juridical form, but as a guiding principle among people and between them and their territory. The cooperative spirit as a relational good materialises the formal systems of governance, extending their capacity to share means and goals from a multi-stakeholder perspective. On this foundation, emerging initiatives take form, such as new community cooperatives originating from new processes of self-organisation and co-management that cannot be completely derived from spinoffs of pre-existing initiatives. In fact, they are infrastructures working as platforms that can be used for multiple functions and enable the production of different categories of goods due to being managed as commons (Sacconi and Ottone, 2015).

\section{References}

ASC (2013). Social Enterprise \& Biosphere Reserves Development Framework. Edinburgh Scotland, UK: Assist Social Capital CIC. Author: C. Campbell. Available at: http://social-capital.net/wp-content/uploads/2014/03/SEBRFinal.pdf [Accessed: January 2017].

Barca, F., Casavola, P. \& Lucatelli, S. (2014). A Strategy for Inner Areas in Italy: Definition, Objectives, Tools and Governance, Materiali Uval, no. 31. 
Battistoni, F. \& Zandonai, F. (forthcoming in 2017). La rigenerazione sociale nel dominio dei commons: gestione e governo dei community asset ferroviari, Territorio. Milano: Franco Angeli.

Borzaga, C. \& Zandonai, F. (2015). Editoriale: Oltre la narrazione, fuori dagli schemi: i processi generativi delle imprese di comunità, Impresa Sociale, n. 5, numero monografico "La morfogenesi dell'impresa di comunità. Processi generativi, forme organizzative e percorsi di institution building". Available at: http://www.rivistaimpresasociale. it/archivio/itemlist/category/94-5-2015.html [Accessed: June 2017].

Euricse (2016), Libro bianco. La cooperazione di comunità. Azioni e politiche per consolidare le pratiche e sbloccare il potenziale di imprenditoria comunitaria. Testo a cura di Bodini, R., Borzaga, C., Mori, P.A., Salvatori, G., Sforzi, J., Zandonai, F. Trento: Euricse. http://www.euricse.eu/wp-content/uploads/2016/05/Libro-Bianco.pdf [Accessed: June 2017].

European Commission, Directorate-General for Employment, Social Affairs and Inclusion (2016). Social Enterprises and their eco-systems: developments in Europe. Luxembourg: Publications Office of the European Union. Authors: C. Borzaga \& G. Galera.

Borzaga, C. \& Tortia, E.C. (2017). Co-operation as Co-ordination Mechanism: A New approach to the Economics of Co-operative Enterprises. In: J. Michie, J. Blasi \& C. Borzaga (Eds.), The Oxford Handbook of Mutual, Cooperative and Co-Owned Business. United Kingdom: Oxford University Press, pp. 55-75.

Colucci, A. \& Cottino, P. (2015). Resilienza tra territorio e comunità. Approcci, strategie, temi e casi. Fondazione Cariplo. Quaderni dell'Osservatorio, no. 21.

Cottino, P. \& Zandonai, F. (2012). Progetti d'impresa sociale come strategie di rigenerazione urbana: spazi e metodi per l'innovazione sociale, Euricse Working Papers, 42/12. Trento: Euricse. DOI: http://dx.doi.org/10.2139/ ssrn.2141653

Daskalaki, M., Hjorth, D. \& Mair, J. (2015). Are Entrepreneurship, Communities and Social Transformation related? Journal of Management Inquiry, 24(4): 419-423. DOI: https://doi.org/10.1177/1056492615579012

Dasgupta, P. (2004). Human Well-Being and the Natural Environment. New York: Oxford University Press.

Domanski, D. \& Kaletka, C. (Eds.) (2017). Exploring the Research Landscape of Social Innovation - A deliverable of the project Social Innovation Community (SIC). Dortmund: Sozialforshungsstelle.

Farina, E., Teneggi, G., Venturi, P. \& Zandonai, F. (2017). Tesi battagliere sul fare impresa di comunità, Animazione sociale, (308): 23-31.

Foster, S. \& Iaione, C. (2016). The City as a Commons, Yale Law \& Policy Review, (34)2: 281-349.

MacPherson, I. (2013). Cooperatives' concern for the community: from members towards local communities' interests, Euricse Working Papers, 46/2013. Trento: Euricse. DOI: http://dx.doi.org/10.2139/ssrn.2196031

Ministero dello Sviluppo Economico-Invitalia (2016). Studio di fattibilità per lo sviluppo delle cooperative di comunità, Roma, Progetti di frontiera per le cooperative. Available at: http://www.sviluppoeconomico.gov.it/images/ stories/documenti/STUDIO_DI_FATTIBILITA_PER_LO_SVILUPPO_DELLE_COOPERATIVE_DI_ COMUNITA.pdf [Accessed: June 2017].

Mori, P.A. (2017). Community Co-operatives and Co-operatives Providing Public Services: Facts and Prospects. In: J. Michie, J. Blasi \& C. Borzaga (Eds.), The Oxford Handbook of Mutual, Co-operative and Co-Owned Business. United Kingdom: Oxford University Press, pp. 184-194.

Parco Nazionale Appennino Tosco-Emiliano (2014). Rete MaB UNESCO - Candidatura dell'Appennino Tosco Emiliano. Vision e documento di indirizzo al "Piano di Gestione e Sviluppo". Available at: http://www.mabappennino.it/ pdf/Vision-della-candidatura.pdf [Accessed. March 2017].

Pestoff, V. (2012). Co-Production and Third Sector Social Services in Europe: Some Concepts and Evidences, Voluntas, (23)4: 1102-1118. DOI: https://doi.org/10.1007/s11266-012-9308-7

Riddell, D. \& Moore, M. (2015). Scaling Out, Scaling Up, Scaling Deep: Advancing Systemic Social Innovation and the Learning Processes to Support it, The Journal of Corporate Citizenship, No. 58. 
Rizzi, P. \& Teneggi, G. (2013). Ri-conoscere la montagna: il caso dell'Appennino Reggiano. In: F. Ferlaino \& F.S. Rota (Eds.), La montagna italiana. Confini, identità e politiche. Milano: Franco Angeli, pp. 83-108.

Sacchetti, S. \& Campbell, C. (2017). Biosphere Reserves: an "Enabling Space" for Communities, Journal of Entrepreneurial and Organizational Diversity, 6(1): xx-xx. DOI: http://dx.doi.org/10.5947/jeod.2017.002

Sacchetti, S., Christoforou, A. \& Mosca, M. (Eds.) (forthcoming in 2018). Social Regeneration and Local Development. Cooperation, Social Economy and Public Partecipation. London: Routledge.

Sacconi, L. \& Ottone, S. (Eds.) (2015). Beni comuni e cooperazione. Bologna: Il Mulino.

UNESCO (2015). Man and the Biosphere Programme. Available at: www.unesco.org/new/en/natural-sciences/ environment/ecological sciences/man-and-biosphere-programme/ [Accessed: December 2016].

Utting, P. (Ed.) (2015). Social and Solidarity Economy: Beyond the Fringe. London: Zed Books. 